\title{
REINACH AND KANTOROWICZ: JUSTICE, PHENOMENOLOGICAL REALISM AND THE FREE LAW MOVEMENT
}

\begin{abstract}
Adolf Reinach met and befriended Hermann Kantorowicz in one of Lujo Brentano's political economy seminars during the 1901/1902 academic year at the University of Munich. After Munich, Kantorowicz would go on to be a major contributor to the Free Law Movement (Freirechtsbewegung) in Germany and play an important role in the development of the sociology of law in the $20^{\text {th }}$ century. Reinach encountered the work of Edmund Husserl while studying with Lipps and later became central to the phenomenological movement in Göttingen. But all the while he remained interested in and focused on issues related to justice. His last scholarly publication before leaving for battle in WWI, Die apriorischen Grundlagen des bürgerlichen Rechtes (The a priori Foundations of Civil Law, 1913) published in the very first edition of the Jahrbuch für Philosophie und phänomenologische Forschung (Yearbook for Philosophy and Phenomenological Research) is a testament to this. Here we see Reinach taking his phenomenological education and applying it to entities of justice. I believe Kantorowicz inspired this lasting interest in matters of justice.

This essay will focus on the influence of Kantorowicz on Reinach, and while doing so attempt to flesh out and contrast the ways in which these two men sought to overcome the problems of justice (Recht) of their time. Many of these problems still continue to be relevant today.
\end{abstract}

Keywords: Reinach, Kantorowicz, Justice, Free Law, Phenomenology.

In 1901, at the age of 17, Adolf Reinach entered the University of Munich. His main areas of study at that time included psychology and philosophy under Theodor Lipps, and then jurisprudence, which he studied with Lujo Brentano and Ernst Beling, and where he befriended Hermann Kantorowicz. ${ }^{1}$ Although Reinach encountered the work of Edmund Husserl while studying with Lipps, and later became central to the phenomenological movement in Göttingen, he remained interested in and focused on issues related to justice until he left to fight in WWI. When we look at the small body of work he left behind, the

${ }^{*}$ Sessional Instructor for Philosophy, Women's Studies, and Social Justice \& Peace Studies (a) King's University College (Western); Associate Editor for Journal of Camus Studies; Treasurer, The North American Society For Early Phenomenology (NASEP), kbaltzer@uwo.ca

${ }^{1}$ Both Adolf and his younger brother, Heinrich, pursued law studies. Heinrich survived WWI and practiced law until the late 1930s, when the rise of National Socialism forced him to flee Germany. 
largest works are on law: The doctoral dissertation Über den Ursachenbegriff im geltenden Strafrecht (On the Concept of Cause in the Prevailing Penal Law, 1905) and the essay Die apriorischen Grundlagen des bürgerlichen Rechtes (The a priori Foundations of Civil Law, 1913), published in the second part of the first volume of the Jahrbuch für Philosophie und phänomenologische Forschung (Yearbook for Philosophy and Phenomenological Research). The latter work is one of his most important, and here we see the exploration of concepts such as essence, state of affairs, and the a priori - all in relation to legal entities. I believe that what interested him first and foremost was the essence of justice (Recht), its ontological status and grounding, and how we as humans apprehend it and its laws. Secondary to this, but necessarily connected with it, was his interest in how the system of codified law (Gesetz) participates with justice. ${ }^{2}$ His training in philosophy, phenomenology, and psychology enabled him to explore jurisprudence in novel ways: he was truly a phenomenologist of law.

In this essay, I will turn my focus to the influence of Kantorowicz on the jurisprudential ideas of Reinach, as this relationship has received very little attention despite its direct relevance to contemporary discussions of law. Both Reinach and Kantorowicz leveled powerful critiques at the legal science of the early $20^{\text {th }}$ century, specifically the Bürgerliches Gesetzbuch (BGB; German Civil Law Code) of 1900, and the dominance of legal positivism. While their critical views about the new law code and positive law have a great deal in common, differences do become apparent when we analyze the approach each takes to discussing entities of justice and the resolutions each proposes of the current issues in law. These differences, I believe, are a result of their academic training, inclinations, and perception of the nature of justice. Reinach, the phenomenological realist and admirer of Aristotle and Husserl, attempts to ground Recht ontologically, so that it can be seen as an essence that ontologically supersedes codification, and is yet still in the world; and in doing so he provides the solid foundation for its practice (similarly to how Husserl had conceived phenomenology as providing a foundation for the sciences). By revealing the ontological status of Recht, Reinach could restore to it its authority and glory - something Leibniz sought to do - and then delve into its essence in ways not attempted previously. In contrast, Kantorowicz is speaking to procedure and seeks to liberate Recht in social-political ways related directly

${ }^{2}$ The choice of preposition here - 'participate with' - is a deliberate one and is intended to reflect the idea that an individual thing or being is not static, but rather is engaged in essential activity: "the activity in and through which its matter was being informed" (Mitscherling 2010, 83). This should more clearly capture the sense of Aristotle's Formal Causality and Plato's notion of Participation. My hope is to avoid the confusion or conflation of participation with imitation, which happens when phrasing like 'participate in' is used. To subsist or obtain at all, essence and entities like justice must do so through participation. 
to the process of adjudication: the role of judges should be to create new law and find justice. Law, he says, should not be purely state-decreed. Both Reinach and Kantorowicz seek to free justice (Recht) from the legal scientists; however, their points of view on where the essence of justice resides are very distinct. Still, that is not to say that ultimately we cannot find some complementary aspects between the two approaches.

In what follows, I will discuss the influence of Kantorowicz on Reinach and while doing so attempt to flesh out and contrast the ways in which these two men seek to overcome the problems of justice (Recht) in their time. Many of these problems continue to be alive today.

\section{THE FRIENDSHIP OF REINACH \& KANTOROWICZ}

Kantorowicz was roughly 6 years older than Reinach, and obtained his doctorate in 1904 at Heidelberg with a dissertation on the history of criminal law. Reinach met Kantorowicz at the University of Munich in one of Lujo Brentano's political economy seminars during the 1901/1902 academic year (Schuhmann, Smith 1987, 6). It can be easily surmised that the two hit it off: Reinach followed Kantorowicz to Berlin for the summer semester of 1903, studying primarily jurisprudence, and Kantorowicz told Gustav Radbruch in a letter how impressed he was with Reinach's considerable talents and aspirations (Schuhmann, Smith 1987, 6). It may be of interest to note here that after Reinach defended and published his doctoral dissertation, Radbruch wrote a scathing review of it. He accused Reinach of espousing a method of interpreting the concept of law solely through the intentions of the law-giver. In response to this accusation and harsh review, Kantorowicz sent a strongly worded letter to Radbruch: "Now I must really read you the riot act! How could you go down on poor Reinach in that way? ... Someone like him deserves to be encouraged, not intimidated. And what's more important is that he is someone who belongs with us with his every inclination" (Schuhmann, Smith 1987, 7). I mention this because it shows how impressed Kantorowicz was with Reinach's intellectual spirit and capabilities. I believe that Kantorowicz played a crucial role in the development of Reinach's ideas on the nature of justice through their fruitful dialogue about the problems with Germany's new BGB and its implementation. Evidence for this is found in Die apriorischen Grundlagen des bürgerlichen Rechtes (1913), which on the whole serves as a phenomenological critique of the BGB. 


\section{ON GERMAN LAW: RECHT VS. GESETZ}

It is necessary to elaborate on an important distinction that we find in the German language of law, one that lacks an English equivalent. ${ }^{3}$ As students of jurisprudence in Germany, Reinach and Kantorowicz would be well versed on two different senses of justice: Recht (i.e., ius, droit) and Gesetz (i.e., lex, loi). The former sense of justice is understood as a transcendent unity or harmony subsisting in the universe, one that humans can access through using insight that is rational - thus linking it to an activity of thinking. The latter sense is understood as something achieved exclusively through codification - that is, through adhering to written laws constructed by humans. The difference boils down to origin and source of power: with Recht, humans can have insight into it, but they do not create it and its power is beyond their reach; whereas Gesetz is created by humans and derives its power from the state. In a perfect situation, Gesetz should be derived from and actively participate with Recht. However, the tie between the two became looser with each new law code proposed in Germany (BaltzerJaray 2016). Furthermore, the growing dominance of scientific method and the accompanying perception that it was the only way to obtain truth and certainty (i.e., to be considered legitimate, justice had to be grounded in scientific principles) resulted in more attention and credence being given to Gesetz. Jurisprudence as 'Legal Science' was born, and even though two distinct traditions evolved, both rely heavily on science in their approach and/or valuing of method, reasoning and truth. ${ }^{4}$

The result of this loosening of the ties between Recht and Gesetz that took place over a century and a half in Germany was the BGB of 1900, where the law became the servant for the achievement of ends, those ends being the economic good of society, and hence - now a political project. Law was a technical instrument for the pursuit and achievement of social, economic, and political aims. It required judges to apply the laws as written and interpret them to suit concrete cases: a trained judge would abstract and reduce a case to its basic legal concepts, then find a resolution by aligning those concepts with the rules in the code. In the system of positive law, justice is achieved with the logical subsumption of any particular case under that code: "Everything a judge needed to know about the civil law was contained in the BGB or could be deduced from it directly or from the concepts that its terms implied. The law was autonomous, deductive, authoritative, positive, and, through its organic unity, provided the answer to every possible case that could come before a judge" (Herget, Wallace 1987, 407). Thus, the BGB presented law as a logically closed system, one with its own interrelated

${ }^{3}$ This distinction exists also in French, Latin, and Greek, and several others. In English the word 'law' is used interchangeably to mean both codified law and justice.

${ }^{4}$ For more discussion on this topic, see: Coyle, Pavlakos (2005). 
principles, rules and concepts (Herget, Wallace 1987, 407). It is also important to note that BGB as a positive law project sought to end any existing confusion or conflation of law with morality. This divorce of law from morality was also intended to extinguish in politics and jurisprudence schools any remaining traces or power of natural law (i.e., those unchanging moral principles, usually set by God, that govern the universe and serve as the foundation for our conduct and understanding of right and wrong).

An important function of a law code like the BGB was to serve as a standardized and authoritative approach for overcoming legal gap problems. While there are numerous kinds of gaps that can arise in law, a few of them are relevant to the discussion here. First, there is the case of non liquet, which is a legal gap situation where there is no applicable law (also known as extra legem gap) - in other words, when a case or legal issue comes to light that is not explicitly dealt with in the law code. Another type of legal gap occurs when the language of the legislator creates loopholes due to inadequate, equivocal, or vague wording. These are also referred to as indeterminacy or interpretational gaps (i.e., intra legem gap). In the late $19^{\text {th }}$ century, during the drafting of the BGB, the resolution of these sorts of gap problems was rooted in the question of what the legitimate source of the law was: "From what authority can a judge draw the rules or principles that justify his decision? More specifically, it might be termed the 'gap' problem: when positive law is unclear or does not appear to address a question presented by a case, where can the judge go for guidance?" (Herget, Wallace 1987, 403). Now, the answer to this question was different for each of the law schools, which complicated matters immensely. Judges' decisions of how to interpret a law for a case where a legal gap occurred were the result of which school of law they were educated in or supported, and thus there was little consistency. Natural law supported the idea that God or Nature was the source for the law, and this view was associated with the church and morality, while the Positivist School saw no gap problems at all - the issues that arose pertained largely to the meaning of words and logic, and thus a legal scholar could explain the proper meanings and resolve all the issues (Herget, Wallace 1987, 404). Then there was the Historical School, which perceived law as connected to the culture of the people (Volksgeist), and it would evolve organically with the change of time and progress of society. The Historical School, just like the Positivist School, did not recognize any universal precepts of law. In the $19^{\text {th }}$ century, reason came to have a special role, especially as society grew in complexity and came to require jurists for the drafting and interpretation of its laws. Reason would also solve the gap problem by offering a more extensive and penetrating analysis through the invocation of more general concepts and more careful use of logic and terminology (Herget, Wallace 1987, 406). However, when such gaps still surfaced, judges would turn to the 'organic meaning of the law as a whole' - which included a careful examination of the nation's legal system and the culture of the people (Herget, Wallace 1987, 406). 
After 1870, Germany was politically unified and there was some pressure to establish unity across the once independent states, each with its own distinct culture, customs, and slight variations of Roman law traditions (in their medieval version). This unification was a major impetus for selecting a committee to draft a new general law code for the country. The Positivist and Historical Schools came to dominate the legal landscape, since the legal scientists who drafted the BGB showed allegiance to these schools of law. Hence, the code is a fusion of the two schools, as are the adopted solutions to gap problems.

The first paragraph of the first draft of the BGB stated that if there were an instance where the law book contains no rule to apply (non liquet or extra legem gap), then a judge should look to precedent, and if that does not exist, then 'the spirit of the legal order' (Rechtsordnung) should determine the ruling. It is worth noting that this paragraph was eventually cut from the final version of the BGB. This 'legal order' - according to Bernhard Winscheid, the highly influential $19^{\text {th }}$ century author of the Textbook of Pandect Law (Lehrbuch des Pandektenrechts) and inspirational source for the BGB - was the higher source of law upon which any application of a legal code must depend. But that legal order was not the traditional understanding of Recht; rather, it was constructed and willed by the people, and was situated between the transcendent, unknowable, ideal of justice and the posited law. Importantly, the legal order was also to be understood as separate from the moral order of society. Law and morality should never be confused; the civil law brandished the full and only stamp of authority.

In much of the sociology of law literature, the very field that Kantorowicz would come to heavily influence, the 'Gap Problem' is a particular focus on or concern with the problem of disjunctions between promises or claims intended by laws and the actual effects of those laws; or, in other words, on the problem of the discrepancies between the law in books and the law in action with its real-world consequences (Nelken 1981, 41). This concern looked at the effects of the law on the social environment, and research would later extend this focus to understanding how legal decisions in developed countries affect those in the developing ones (e.g., how Supreme Court decisions in the USA on race or gender might penetrate into the legal structure of developing nations and lead to social change).

Reinach, Kantorowicz, and many other legal scholars of the early $20^{\text {th }}$ century were very critical of and angered by the BGB, with its overreliance on and preference for Gesetz, and of the concept of the legal order that served as its underpinnings - which was divorced from the old and traditional sense of Recht. 


\section{KANTOROWICZ \& FREE LAW}

As mentioned, Kantorowicz was a major contributor to the modern Free Law Movement (Freirechtsbewegung) in Germany around 1906/1907, and he played a crucial role in the development of the sociology of law in the $20^{\text {th }}$ century. 'Legal skepticism' is the best way to sum up the wide array of ideas central to it. The central period of the movement is usually held to be from 1899 until 1912, but no clear demarcations really exist. For example, as early as 1861, skeptical views are expressed by legal scholars, such as the statements made by Rudolf von Jhering about drafts of the BGB and the approach to the 'Gap Problem,' and we see continued advocation for Free Law positions as late as 1929 - in essays by the writer Ernst Fuchs (Herget, Wallace 1987, 402). Although the Free Law Movement never attained the status of a school of thought, its intellectual consequences are still visible today in both Germany and the USA.

In a 1906 pamphlet titled "The Battle for Legal Science" (Der Kampf um die Rechtswissenschaft), published under the pseudonym Gnaeus Flavius, Kantorowicz sought to unify the growing number of legal scholars critical of the legislative aspect of judicial decisions in the BGB. He argued that judges should not simply apply the law but they should create it whenever there is a gap or issue in a statute. ${ }^{5}$ He felt that a major consequence of positivist legal theory was that a judge became merely a 'subsumption automaton' practicing 'analytical jurisprudence' that failed to take important factors into account, like emotions. Free law, for Kantorowicz, consisted of custom and usage, but also judicial opinions and authoritative statements of legal scholars. The administration of law, he argued, should be placed in the hands of judges who are willing to invoke free law and possess the education befitting such a task, which would include political science, economics, psychology, philosophy and criminology. His was a resurrection of natural law, but in a renewed form - understood as a type of law liberated from the strictures of state decree. He writes,

As much as our free law corresponds with natural law at this central point, it is worth stressing again that our movement's conception of law is forever separate from natural law's. Because we can see the valuable judicial insights of the thinkers of the seventeenth and eighteenth centuries without needing to assume their metaphysical fallacies; for us sons of the nineteenth century, the world is eternally transforming and developing, and our free law is as transient and frail as the stars themselves. In fact, in a secondary respect, our conception of law is opposed to natural law's. The Historical School has taught us to acknowledge all law, and therefore all free law, as such only when it is 'positive.' We were taught that law exists not in nature, but

${ }^{5}$ The choice of his pseudonym was intentional since Gnaeus Flavius was a Roman legal writer and politician who made public the rules of legal procedures (actions in law) which had previously been kept secret by the Patricians. Making these rules public knowledge ended the advantage the Patricians had over the citizenry/plebeians and led to the publication of law codices. 
if and only if a power, a will, an acknowledgement supports it. Our free law is, however, also a natural law-the natural law of the twentieth century (Flavius 2011,6).

He reinforces this point, adding the following:

And this free law, so unexpectedly returning from its disappearance in legal theory, proves itself to be at least equal to statutory law in power and influence. It has the great advantage over statutory law that people are familiar with it. People hardly know statutory law, or more specifically, as M. E. Mayer noted, know it only when it agrees with them, but that is luckily often the case... Who could imagine a traveler in a strange land making himself familiar with the language, history, art, folk traditions, simply by opening his civil statutory code? No one! They all live according to free law, according to what strikes the bylaws of their particular domain or their individual judgment not as arbitrary, not as convenient, but as law. Thus, free law cultivates its powerful domains and lives independently from the statutory. But not the other way around. Free law is the basis from which statutory law proceeds (Flavius 2006, 5-6).

This free law that Kantorowicz pursues has justice moving away from the strict language of statues and into the domain of what he calls the 'science of values' (to be distinguished from the science of facts and the science of meaning), and it does so in ways that can be described as relativistic. Free law is a resurrection of natural law but in a changed form, one that emanates from the natural relationships of individuals in society, and hence it can be perceived in the norm-consciousness of people interacting in concrete situations (Flavius 2006, 4). However, with that there are some rather unsettling consequences: In addition to the obvious issues connected to relativism and justice, he and the Freirechtsbewegung have been described as also providing a sustainable legal foundation that is capable of meeting the political demands of socialism. It should be mentioned that Kantorowicz joined the Social Democratic Party while a student at the University of Berlin and, though he resigned in 1904, he admitted to retaining a kind of "Platonic love" for socialism. He was also an admirer of the sociology of Max Weber. While Reinach shares Kantorowicz criticisms of legal positivism, he would no doubt disagree with where he takes justice once he frees it. Relativism doesn't restore authority to Recht nor does it describe its essence.

\section{A PRIORI FOUNDATIONS OF RECHT - REINACH'S CONTRIBUTION}

I argue that Reinach's essay "The a priori Foundations of Civil Law", in addition to serving as a response to the BGB, is also a reply to Kantorowicz. In this article, there are two avenues that Reinach pursues regarding justice as Recht: the psychological and, most importantly, the ontological. The former works as an elaboration of what Kantorowicz says, but utilizes the training in descriptive psychology and phenomenology that Reinach received as a student of Lipps and Husserl. The latter, the ontological, speaks specifically to the ontological foundation of Recht (as justice) that should ground codes like the BGB and the 
contractual relationships of individuals in society, and thus serves as a critical response to Kantorowicz' sociological conception of law.

First, what I think inspires Reinach about Kantorowicz' notion of free law is that it describes justice (Recht) as something people naturally understand, prior to any reading of statutes. Hence his title and discussion of 'a priori foundations', and his delving into entities like speech acts - which clearly show how people understand justice in their daily lives without consulting books of positive law or legal scholars. Further to this point, and again in line with Kantorowicz, Reinach would also support judges creating new law when legal gaps arise, rather than being 'subsumption automatons' practicing a purely analytical approach. Justice in the creation of a new law or a creative ruling can be achieved when jurists and judges employ their insight into that transcendent unity of Recht that subsists in the universe.

The purpose of the first section of Reinach's journal article is not only to discuss the ontology of speech acts and their objects, but also epistemology - since he will demonstrate that they have their basis in the a priori theory of Recht: speech acts and their objects are not simply social constructs, given that their self-evidence allows them to be known with certainty, clarity, and by everyone. (Reinach as a phenomenological realist does epistemology at the same time as metaphysics.) Social acts have a natural binding power outside of the positive law. Many instances of social relations do not enter into the realm of law, and many do not need a legal contract at all - such as the relation exhibited in the statement, 'I promise I will buy you a lollypop'. Everyone knows what a promise entails and what it 'means' in so far as it imposes a claim and obligation between people. Reinach also wants to prove that the positive law itself must assume the very idea of an a priori theory of Recht in order to enact codes in the first place. In fact, he says that the a priori theory of Recht underpins all forms of law. He writes, "In what follows, we limit ourselves to presenting some a priori foundations of civil justice. We are convinced, however, that the other legal disciplines - particularly criminal justice, public and administrative law - are also capable and in need of such a founding" (Reinach 1989, 145 fn.). Just like Kantorowicz, Reinach is opposing the stance of positive law (also the BGB), one that amounts to saying that there are no such things as justice or legal principles (rechtliche Gesetze) that remain independently and timelessly valid - like the principles of mathematics. Further, one also cannot encounter these simply by looking at a psychology operative in the everyday interactions of people.

We arrive at an analysis of claim and obligation, at Reinach's famous argument. Like trees and grass, claim and obligation also have an independent being; what makes them different is that when something is predicated of a particular legal entity, the predication refers to any entity of this kind, not just a specific individual. He writes, "That a claim is settled by a waiver is grounded in the essence of the claim as such and thus holds necessarily and universally. 
A priori propositions hold for juridical structures [rechtlichen Gebilden]" (Reinach 1989, 144). ${ }^{6}$ Thus, Recht as an entity and structure has an a priori character owing to this universality and necessity, and it is one of many in a vast realm, which Reinach says can be 'strictly formulated' according to evidence that enables them to be known clearly by insight. Entities like Recht are independent of any mind that perceives them and, most importantly, independent of any positive law code. Reinach uses mathematics and numbers as an analogy: numbers have an existence independent from the calculations, equations, etc. of mathematicians. Just as mathematicians can manipulate and use numbers in various ways, so too can the positive law manipulate and transform Recht as it requires. However, "The positive law can appropriate them [ewige Gesetze] into its sphere, it can also deviate from them. But even when it perverts them into their contrary, it cannot affect their own intrinsic content [Eigenbestand]" (Reinach 1989, 145). Once again, Recht is something positive laws can participate with, but those laws cannot affect or create it.

He continues this line of argument in a discussion of property rights and obligations - power, right, ownership, lien, transfer, multiple owning parties, economic value, and the nature of representation by proxy. As before, he utilizes the same procedure with each of the above: first, he demonstrates how it is actually part of the a priori theory of Recht and how it has power or meaning outside the positive law, and then shows how the positive law actually assumes or relies on the a priori theory.

This leads to the second and critical part of Reinach's reply to Kantorowicz - the greater ontology of Recht. In his pamphlet, Kantorowicz states that the figures of the $17^{\text {th }}$ and $18^{\text {th }}$ centuries committed metaphysical mistakes. While this comment is not false by any means, I think Reinach saw this comment as an opportunity to prove that an ontology of Recht can be revealed: using his training in phenomenological realism, Reinach will demonstrate that Recht and entities of jurisprudence can have proper metaphysical foundations. Reinach argues that the scientific approach is not appropriate for this task; rather, a philosophical approach like the phenomenological method is necessary for a clear understanding and apprehension of the special character of Recht. He writes that his intention is to demonstrate, "...that the structures which are commonly designated as specifically juridical possess a being no less than numbers, trees or houses do; that this being is independent of whether or not it is grasped by humans, that it

\footnotetext{
${ }^{6}$ Reinach's denotation for the word 'claim' [Anspruch] is not the conventional one. It takes on a legal significance for him when it is linked to promise: it is a demand or request for something considered one's due, a right to something as part of an oral or written contract. It is a bond formed between two parties where, "the one can demand something and the other is obliged to fulfill it or grant it. This bond shows up as consequence or product (as it were) of the promising" (Reinach 1989, 147). Claim and obligation are causally linked when a promise is made. Once the promise is fulfilled, the claim is waived and the obligation is cancelled by being satisfied.
} 
is independent, in particular, of all positive laws. It is not only false but, for all intents and purposes, meaningless to designate juridical structures as inventions of positive law - just as meaningless as it would be to call the establishment of the German Reich, or some other historical event, a fabrication of Historical Science. We really do have before us what is so fervently denied: positive law finds already there [or encounters] [ findet $v$ or $r$ ] the juridical concepts that enter into it; it in no way produces them (Reinach 1989, 143). Reinach stresses that the positive law encounters legal concepts: "it in no way produces them." Legal entities have irrefutable evidence that enables them to be known with insight, since they subsist independently of the mind that grasps them and the positive law code that employs them. He adds:

If there are juridical structures and entities that in themselves subsist [seiende] in this manner, a new domain opens up here for philosophy. As ontology or a priori theory of objects, philosophy has to be concerned with the analysis of all possible kinds of objects as such. We will see that here [juridical structures] philosophy encounters a whole new kind of objects - objects that do not belong to nature in the authentic sense, that are neither physical nor psychical, and that at the same time, owing to their temporality, also differ from all ideal objects. The laws that apply to these objects [juridical structures] are also of the highest philosophical interest (Reinach 1989, 145).

With the mention of philosophy as ontology and this new kind of object - one that is not physical, psychical or ideal - what remains, I have argued elsewhere, can be labeled an intentional entity (Baltzer-Jaray 2016, 65-76). Recht subsists in the world independently of the mind and we become conscious of it when we engage with its intentional structure. It subsists independently of all created laws and theories of ethics; if anything, it is the foundation of these. Recht, subsisting through time as part of the unity of our universe and as intentional structure, makes the concretization of justice and any legal principle possible. The intentional structure of Recht informs or guides our experience of justice, and thus also our behavior. He therefore describes a metaphysical footing for justice (Recht) with no need for God as the source - as was necessary for Leibniz and many other metaphysical thinkers of the $17^{\text {th }}$ and $18^{\text {th }}$ centuries - and with the added bonus of a phenomenological analysis and descriptive psychology dedicated to exactness. Most importantly though, justice (Recht) as described here cannot be relativistic; it cannot just be present in the relationships of individuals, but rather it must be the foundation for these encounters - and for the universe where we find ourselves.

Ontology is the biggest difference between the approaches of Reinach and Kantorowicz. Reinach's accomplishment in this essay was to show how the ontology of phenomenological realism can underpin social relationships, and to demonstrate clearly at the same time that justice is an entity subsisting independently from statutes. Kantorowicz wanted to show that law (as free law) lives independently from the written code, that it cultivates powerful domains, and thus provides the basis from which the statutory proceeds. I would argue that 
Reinach proved this as well, and even more successfully: he was able to restore authority to justice (as Recht) as well as account for psychological/epistemological, metaphysical, and logical aspects of that entity. He gave us the complete package - essence and participation - and made it such that every person can access it with insight. The other avenue available for a rich comparison between Reinach and Kantorowicz concerns natural law. Reinach had a great deal to say about this as well - but that is for another day.

\section{CONCLUSION}

The friendship of Reinach and Kantorowicz was one based on a mutual dislike for the BGB, the dominance of Positivism in law schools and thought, and a deep concern about the growing abyss opening up before their very eyes between Recht and Gesetz. This relationship and the influence of Kantorowicz had a lasting impact on Reinach, as evidenced by his continued interest in matters of Recht after graduating from the University of Munich, and long after he became a central figure in the phenomenological movement. While the style and terminology of Die apriorischen Grundlagen des bürgerlichen Rechtes bears the stamp of his time in Tübingen with legal theorist Ernst Beling (1906/1907), the critical comments about Positivism and the attempt to restore Recht to its former glory as an entity independent of the written law, I believe, show the imprint of Kantorowicz.?

I close this essay with a quote from Reinach, the lines that conclude his 'a priori foundations' work: "It is necessary to turn our gaze in a completely different direction in order to gain access to the realm of the purely juridical lawful regularities [Gesetzmäßigkeiten], which are in every sense independent of 'nature': independent of human knowledge, independent of human organization [Organisation] and independent, above all, of the factual evolution of the world" (Reinach 1989, 277-278).

\section{BIBLIOGRAPHY}

Baltzer-Jaray, Kimberly. 2016. "The Intentional Being of Justice and the Foreseen". In Essays on Aesthetic Genesis. 65-76. Edited by Charlene Elsby, Aaron Massecar. Toronto: University Press of America.

Baltzer-Jaray, Kimberly. 2016. "Phenomenological Jurisprudence: A Reinterpretation of Adolf Reinach's Jahrbuch Essay". In Phenomenology for the Twenty-First Century. 117-137. Edited by J. Aaron Simmons, J. Edward Hackett. London: Palgrave Macmillan Publishers.

Berkowitz, Roger. 2010. The Gift of Science: Leibniz and The Modern Legal Tradition. New York: Fordham University Press. $10-13)$.

${ }^{7}$ For more detail on the influence of Beling on Reinach's essay, see: Schuhmann, Smith (1987, 
Coyle, Sean and George Pavlakos. Eds. 2005. Jurisprudence or Legal Science? A Debate About the Nature of Legal Theory. Oxford-Portland: Hart Publishing.

Flavius, Gnavius. 2006. “The Battle for Legal Science”. Translated by Cory Merrill. German Law Journal 12(11): 2005-2030.

Herget, James E., Stephen Wallace. 1987. "The German Free Law Movement as the Source of American Legal Realism". Virginia Law Review 73(2): 399-455.

Mitscherling, Jeff. 2010. Aesthetic Genesis: The Origin of Consciousness in the Intentional Being of Nature. New York: University Press of America Inc.

Nelken, David. 1981. "The Gap Problem in the Sociology of Law: A Theoretical Review". Windsor Yearbook of Access to Justice 1(35): 35-61.

Reinach, Adolf. 1989. Sämtliche Werke. Edited by Karl Schuhmann, Barry Smith. Munich: Philosophia Verlag GmbH.

Schuhmann, Karl and Barry Smith. 1987. "Adolf Reinach: An Intellectual Biography”. In Speech Act and Sachverhalt: Reinach and the Foundations of Realist Phenomenology. 3-27. Edited by Kevin Mulligan. Dordrecht: Martinus Nijhoff Publishers. 